\title{
Investigating the Relationship Between Informal Economy and Competitiveness in Iran's Metropolises
}

\author{
Ali Asghar Pilehvar ${ }^{1}[0$
}

Received: 17 November 2020 / Accepted: 22 January 2022

(c) The Author(s), under exclusive licence to Springer Science+Business Media, LLC, part of Springer Nature 2022

\begin{abstract}
This article aims to analyze informal economy and competitiveness after the 1979 Revolution in Iran with an emphasis on its eight metropolitan cities. The research method is descriptive-analytical, and data is collected from official resources and statistics. The analysis for data related to economic competitiveness was carried out using technique for order of reference by similarity to ideal solution, entropy, and numerical taxonomy. The results of this study suggest that state modernism has been effective in the growth of urbanization and the decline of urbanization, which has changed Iranians' life patterns from rural to urban in the wake of the 1979 Revolution. There is also a direct relationship between rural-urban migration and informal economic growth in the process of urbanization and urbanization in Iran. The informal economy sector, which accounts for $31 \%$ of Iran's economy, ranks 30th in the world. The survey of informal economy in Iranian metropolises shows that $35 \%$ of its metropolises' GDP comes from the informal economy. The results illustrate the imbalanced employment situation in these metropolises. The highest rate of female and male employees was recorded in Mashhad (81.16 and 90.55) and the lowest in Ahvaz (64.38 and 77.00), respectively. The majority of industrial workers lived in Qom (35.61), and the lowest number of industrial workers was in Mashhad (14.09). Also, the highest number of service workers was in Shiraz (78.40) and the lowest in Qom (54.34). Most of the agricultural labor force lived in Ahwaz (2.74) with Tehran hosting the lowest number of agricultural workers (0.98).
\end{abstract}

Keywords Informal economy $\cdot$ Metropolis $\cdot$ Competitiveness $\cdot$ Structural change

This article is part of the Topical Collection on Interdisciplinarity and Transdisciplinarity in Higher Education, Democracy and Economy

Ali Asghar Pilehvar

pilevar@ub.ac.ir

1 Department of Urban Engineering, Art Faculty, University of Bojnord, 9453155111 Bojnord, Iran 


\section{Introduction}

The trends of urbanization in the world and globalization of cities have provoked structural-functional changes in cities along with rapid and widespread flow of goods and services (Nazmfar et al., 2017). This trend has given rise to concepts such as competition and competitiveness between cities and metropolises (Nejati Hoseini, 2011). According to Peter (2013), the economic competitiveness of large cities and metropolises has been the subject of increasing attention of managers and urban planners in recent decades. This process is associated with reduced costs, raising standards, technology development, and increasing integration into global economic markets (Peter, 2013). On the other hand, the competitiveness of metropolises is closely tied to their potentials to create an economic market. Therefore, production capacity, standard services, exports, and improved quality of life are key factors in the formal and informal economies of metropolises. In underdeveloped and developing countries (such as Iran), structural and functional changes hamper economic growth and productivity because they are associated with high risks and rising prices (Mcmillan et al., 2014). According to Roderick et al. (2016), economic growth in such countries depends on the flow of resources (capital, labor, etc.) from traditional to the modern sectors (Rodrik et al., 2016). The economy of these countries consists of a traditional sector (with formal and informal employment) and a modern sector (with formal employment in urban centers). Iran's economy is characterized by its hydrocarbon sector, agricultural, and service sectors, as well as a dominant presence of government in the manufacturing and financial services. Iran ranks second in the world in terms of natural gas reserves and fourth in terms of proven crude oil reserves. While relatively diversified for an oil-exporting country, economic activities and government revenues still heavily rely on oil revenues and are therefore at the mercy of oil market fluctuations. A survey of the urban and informal economy in underdeveloped and developing countries in both formal and informal sectors suggests informal sector growth in the economic activities of these cities (Veysiyan et al., 2016). It also constitutes informal settlements and suburbs in terms of housing (UN-Habittat, 2006). The informal economy has expanded in recent decades in light of the growing rural-urban migration to major cities. This sector has also contributed to the low economic competitiveness in Iran's metropolises (Ali Akbari et al., 2019). A rigorous analysis of the situation of these metropolises shows that despite the growth of immigrants, poverty, unemployment, etc., the informal sector has made a huge contribution to the economy (Rabbani et al., 2009). In light of the above, the goal of this study is to explore the relationship between two indices of population and urbanization in the informal economy and competitiveness in 8 metropolises of Iran (Tehran, Mashhad, Isfahan, Karaj, Tabriz, Shiraz, Ahvaz, and Qom). It is not intended to develop another index for Iranian metropolises. Instead, the primary goal of this paper is to examine, compare, rank, and improve the informal economy and feasibility competitiveness in metropolitan areas. The selection of metropolises was driven by population criteria (more than 1 million population) and their role as major regional centers in formal and informal employment of the urban economy. By reviewing, comparing, ranking, and analyzing the data available, 


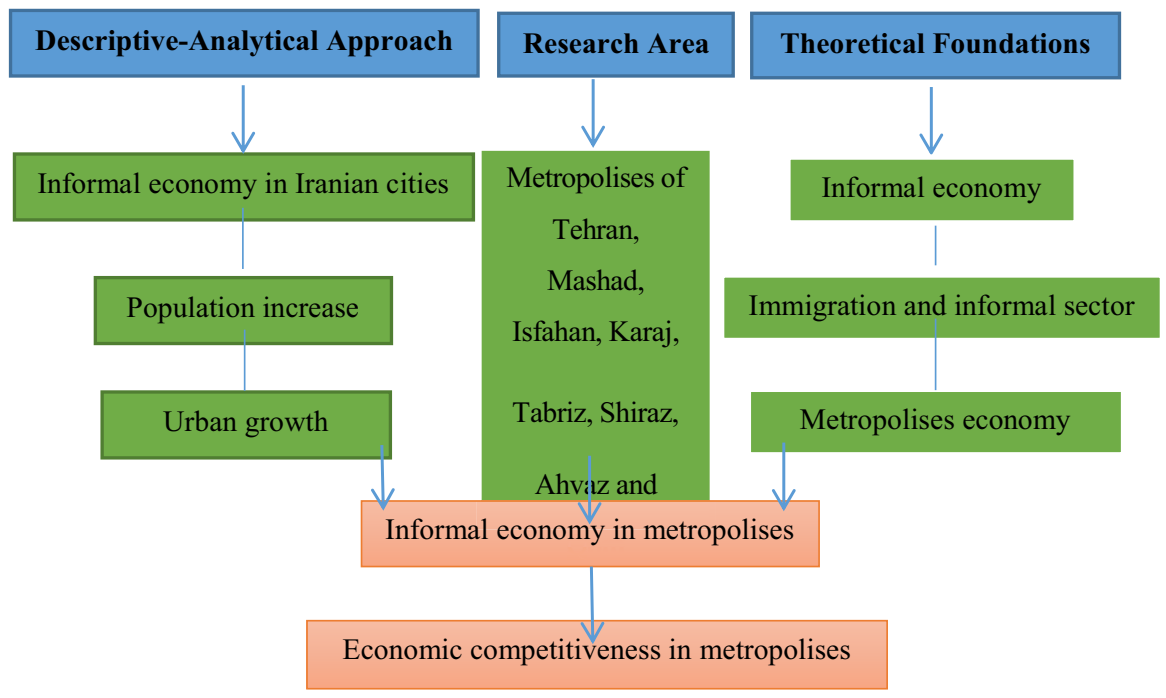

Fig. 1 Conceptual model of research

this study aims to provide deeper insights into the official and informal economies of eight metropolises of Iran based on the population index and their competitiveness at national and international levels. The authors have adopted a cause-andeffect approach to explain and analyze the status of economic competitiveness with emphasis on metropolises on the one hand and to explore the association between informal economy and competitiveness in the urbanization process of Iran. Therefore, to achieve the research goal and confirm the underlying theory of the research, the theories of Douglass North, Dani Rodrik, and Ricardo Hausmann about institutionalism, economic competition (formal and informal), comparative advantage, technical knowledge, and economic complexity are investigated along with the role of competitiveness in Iranian economic viability. Therefore, this study helps review and clarify the status and relationships between informal economic indicators and economic competitiveness in Iranian metropolises. Given the paucity of new and valid data on the research topic, the author has utilized secondary data. The article has a top-down structure and organized according to technique for order of reference by similarity to ideal solution (TOPSIS), taxonomy, and entropy analytical models. To paint a clear picture of the research process, the conceptual model and main research indices are shown in Fig. 1.

\section{Literature Review}

\section{Foreign Researches}

In the 1990s, Porter proposed a model of economic competitiveness for growth and productivity as industrial clusters. A decade later, he concluded that competitiveness 
and competitive strategy in the urban economy lead to social progress and sustainable growth (Snowdon \& Stonehouse, 2006). In 1991, the Journal of Urban Studies published a special issue on urban competitiveness, underlining the inability of national governments to bolster the competitiveness of cities in the economic sector. Müller and Webster (2000) concluded that for cities to be competitive, four variables of regional talent, economic structure, human resources, and social and organizational environment must be accounted for (Müller \& Webster, 2000). In 2011, Papisco explored socio-economic development criteria for prioritizing urban areas in terms of competitiveness. The results demonstrated that the analysis of factors associated with urban competitiveness provides an effective strategy for the urban and regional planning development (Popescu, 2011). Singhal et al. (2013) in a study entitled "an evaluation model for urban competitiveness: the "program for British cities" studied four cities using multi-criteria decision-making, hierarchical analysis, and Delphi. The results of this research suggested that reconstructing the formal business environment in the urban economy is a viral strategy for enhancing the competitiveness of cities (Singhal et al., 2013). The Sally's report (2014) for the World Economic Conference highlights population growth and urbanization, sustainability, and escalating inequality as global trends in the economic competitiveness of cities (Sally, 2014). Kamiya and Ni (2020) in the Fourth Global Urban Competitiveness Report (GUCR) underscored three indices of economy, population growth, and metropolitan system expansion in the process of economic competitiveness (Kamiya \& Ni, 2020). Therefore, the economic competitiveness index of cities provides a framework that reflects the impact of local competition on global competitiveness (Villamejor-Mendoza, 2020). The results of such applied research can provide effective strategies for the competitiveness of Iranian metropolises in the Middle East, marking a shift from an oil-based and informal economy to a productive and formal one.

\section{Iranian Studies}

All national economies have an informal sector, but in the case of Iran, more than one-third of the economy is not accounted for, which complicates accurate measurement of national and per capita income. Economies that struggle with issues such as underdevelopment and poor governance are usually a fertile ground for the emergence of an underground economy. Iran's informal sector, however, has mainly grown due to external sanctions and the complex regulatory environment, which spurs unlicensed activity and tax evasion. Apart from sanctions, the main drivers of the informal sector's growth are smuggling, black market, and corrupt practices. Ironically, there are also legal activities that can be considered as a part of the informal economy. The Iranian economy has a hybrid structure that merges traditional merchant and modern industries. The major upheavals of the past four decades, including Iranian revolution, war, reconstruction, sanctions, and uncertainty, as well as the internal and external transformations, are the main reasons for changing economic structures. Despite various attempts to modernize 
economic structures, Iran still lacks an economic doctrine. A strategy document entitled Vision 2025 represents early efforts to provide such a strategy, but internal and external political events have thwarted its effectiveness. Current policies are formulated in reaction to US-imposed sanctions and revolve around the concept of a resilient economy, but the economy as a whole is at the mercy of stress induced by sanctions and internal challenges (Khajehpour, 2020). In Iran, few studies have explored the relationship between the informal economy and economic competitiveness in the urban system so far. Rabiee and Khajouie (2013) studied the competitiveness of Tehran metropolis relative to other metropolises in developing countries. The results of their research revealed the need for a competitive strategy for Tehran to fuel economic competition (Rabiee \& Khajouie, 2013). In 2014, Delbari explored the determinants of economic competitiveness of cities, which highlighted the need to provide strategies for sustainable economic growth and development (Delbari, 2014). Kargar Samani et al. (2014) looked at the effect of urban competitiveness on national competitiveness, identifying an economically significant relationship between urban competitiveness and national competitiveness (Kargar samani et al., 2014). Yasouri et al. (2015), in their research on trends and policies of centralism in Tehran, explored the situation of Tehran metropolis at the national and international levels. They argued that Tehran could vie with cities such as Ankara and Saint Petersburg (Yasouri et al., 2015). In 2017, Nazmfar et al. studied the economic competitiveness of Iranian cities, concluding that Iranian metropolises have a more desirable status than smaller cities. Accordingly, Tehran is ranked first in terms of economic competitiveness followed by Ahwaz and Isfahan (Nazmfar et al., 2017). In 2019, Pilehvar looked into the social and economic instability of Iran's metropolises. The findings of this study shed light on the growth of the informal sector in the metropolitan areas due to unbridled population growth and urbanization, which has also hampered the feasibility of urban competitiveness (Pilehvar, 2020). Ali Akbari et al. (2019) studied the economic situation of Iran's metropolises, reporting that the economy of these cities is directly related to immigration, and Iranian metropolises are influenced by the formal and informal economy (Ali Akbari et al., 2019). Moreover, the findings of Ziari et al. (2020) showed that Tehran is among the top 3 cities in southwest Asia in terms of ITC- and knowledge-based economy infrastructure, which has stimulated Tehran's economic competitiveness (Ziari et al., 2020). The bulk of these studies has shown that the informal sector of the urban economy is affected by the process of centralization, rural-urban migration, urbanization and urbanity growth, and reduced competitiveness.

\section{Theoretical Foundations}

\section{Economic Competitiveness}

In Douglass North's theory of institutionalism, the concept of economic competition is defined in both formal and informal sectors. The government in the formal sector and ideology in the informal sector play a decisive role in economic competitiveness. 
North's theoretical achievement concerning Iran highlights 3 challenges to a noncompetitive economy: (1) ideologicalization of society, (2) political and economic elites as beneficiaries, and (3) substitution of commitment with expertise. In Iran, ideological governance and the dominance of a corrupt system that favor pressure groups in the political and economic sectors as well as poor specialization in executive management have placed the process of economic competitiveness in conflict with social interests, which has in turn affected the informal economy and debilitated economic competitiveness. Dani Rodrik also underlines the importance of institutionalism in the process of economic growth and development. He believes that democracies are more equipped to cope with external shocks through institutionalization and transparency. The theoretical implications of Rodrik's view on Iran are that the Iranian economy entered a third consecutive year of recession following the triple shock of sanctions, oil market collapse, and COVID-19 pandemic. Gross domestic product (GDP) contracted by $6.8 \%$ in 2019/2020 after US sanction waivers on Iran's oil exports expired. The spread of COVID-19 and the subsequent collapse of oil markets also impacted the last quarter of the year's GDP (ending March 2020) as oil production reached a three-decade low. The theoretical implications of Rodrik's view on Iran is that the Iranian government has confronted a plethora of external shocks in recent decades due to international sanctions, which have slowed or hindered its economic growth. Thus, the recent lackluster growth builds upon a decade-long stagnation. During 2010/2011-2019/2020 periods, GDP grew at an annual rate of $-0.1 \%$, and Iran's per capita GDP fell below regional and income group averages (Fig. 2).

These conditions have contributed to economic instability, rising unemployment, inflation, reduced competitiveness, and increased share of the informal economy. Figure 3 shows the Islamic Republic of Iran/real GDP growth and contributions to real GDP growth (Fig. 3).

According to the most recent figures and financial estimates, 36.5\% of Iran's economic activity is attributed to the informal sector (The World Bank, 2020). Another underlying theory has been proposed by Ricardo Hausmann. He asserts that 3 indices of comparative advantage, technical knowledge, and economic complexity are vital to an accurate economic analysis. According to Hausmann, countries with a comparative edge that manufacture competitive goods using their technical knowledge exhibit a higher level of economic complexity and economic competitiveness. The application of Hausmann's view to Iran suggests that despite several advantages

Fig. 2 Iran's per capita GDP (2010-2021)

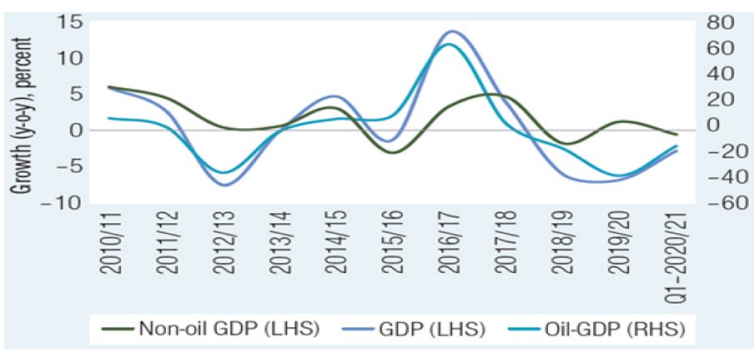




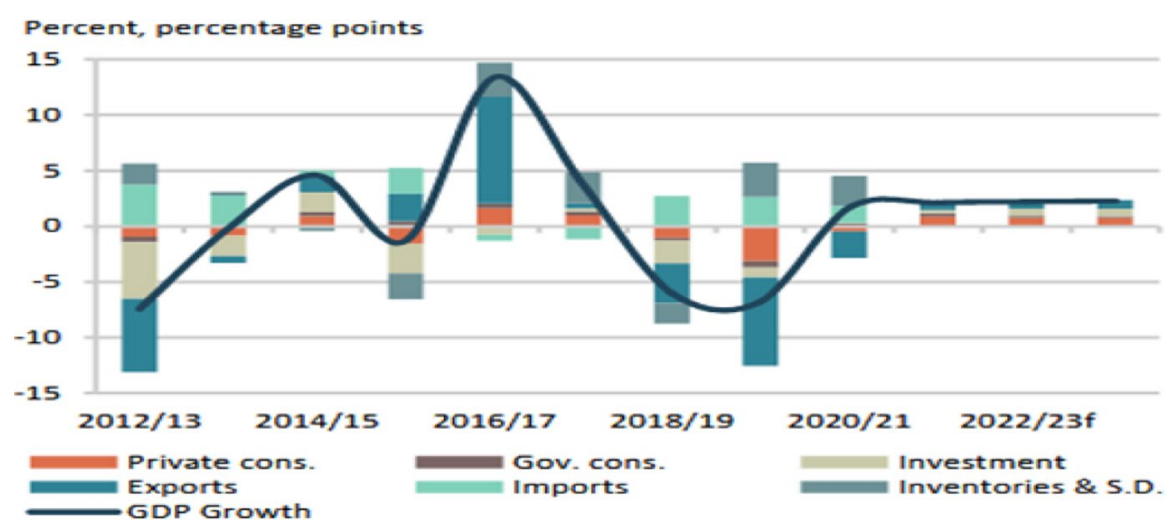

Fig. 3 Iran's real GDP growth and contributions to real GDP growth (2012-2023). Sources: Central Bank of Iran and World Bank's staff calculations

such as vast oil and gas reservoirs, geopolitical position, and access to open waters, the lack of technical knowledge and the domination of international sanctions have stifled sustainable economic competition in Iran. With a negative economic growth rate in the last 10 years, economic development and competitiveness have been hindered or shrank. Latest available CBI data for Iran's GDP confirms that the COVID19 crisis has contracted Iranian economy by $2.8 \%$ in 2020/2021. Figure 4 shows the broad base of recession (Fig. 4). On the production side, the largest driver of this economic contraction was oil sector followed by service sector. This partially reflects the carryover effect of the US sanction waivers that expired in April 2019. This shrinkage was pronounced in services as this sector had only started to recover in the second half of 2019/2020. However, industries (non-oil) and agriculture production continued to grow despite border closures and weak domestic demand.

Merging the theories of Hausmann and Rodrik, it can be concluded that two factors are crucial for a country's economic growth and competitiveness: foreign technology and good institutions (Hausmann \& Rodrik, 2002). Considering the views of these two theorists on the economic situation and the possibility of economic competitiveness in Iran, both factors face obvious challenges in Iran. Firstly, the closed

Fig. 4 Iran's GDP components (2020-2021). Source: Central Bank of Iran and World Bank's staff calculations (2020)

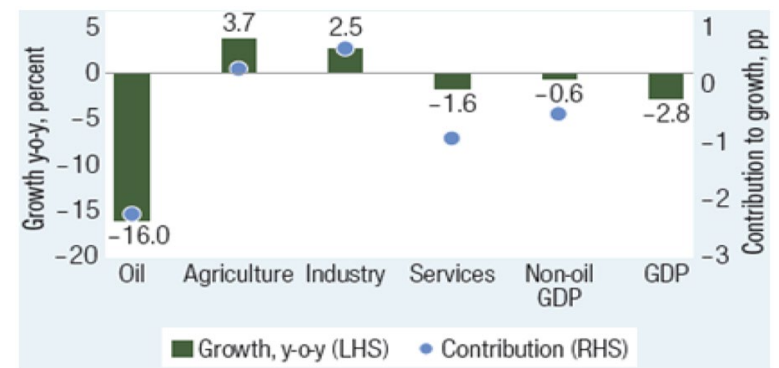


and rent-seeking economy of the government has thwarted foreign investment and the import of advanced foreign equipment, which has pushed back technological growth. Secondly, the socialist government of Iran and its state-centered and centralized economy has obstructed the formation of competent and transparent institutions. Therefore, corruption is rampant, and the competitive economy is booming. Theoretical implication of Hernando de Soto's theory on Iran is that a rent-seeking and centralized economy contributes to the spread of corruption and expedite smuggling processes from Iran to the west (Iraq), east (Pakistan and Afghanistan), and south of the Persian Gulf, which in turn helps the informal sector thrives.

\section{Urban Competitiveness}

In the last two decades, with the escalating globalization of cities and metropolises to attract investment, new technologies and tourism have spurred intense economic competition with other urban areas. Therefore, it can be argued that urban areas, with their shifting role as economic actors, have provoked urban competition (Popescu, 2011). Global indicators of urban competitiveness include GDP per capita, scale, productivity, employment rate, economic growth, number of multinational companies, and price advantage (GUCP, 2010). In this research, two indices of GDP per capita and employment rate have been considered. According to the McKenzie Global Institute, by 2025 , cities will generate more than $80 \%$ of the world's revenue and $60 \%$ of the world's GDP (Eide, 2014).

In its simplest sense, competition is a type of social interaction. However, from a more complex perspective, competition is a struggle entwined with various social, political, economic, urban, etc. relations in the modern era (Mondal, 2021). In a complex and innovative concept in economic policies, competition is used to design strategies and perform comparative analyses (Voinescu \& Moisoiu, 2015). Competitiveness is a key criterion for demonstrating growth and development differences as well as the success of countries in general and cities in particular. Competitiveness is a dynamic process that links a country or city to a competitive advantage or superior position (Vares et al., 2012). Paliulis and Cincikaite posit that urban competitiveness is a set of factors that contribute to the interactions of cities (Paliulis \& Cincikaite, 2013). However, Saez and Perianes see urban competitiveness as an opportunity to meet challenges (Saez \& Perianes, 2015). From another perspective, urban competitiveness indicates the ability of a city to generate wealth efficiently in comparison with other cities (Yang, 2013). This concept has gained recognition as a strategy in recent years (Peter, 2013). Therefore, it is fair to posit that competitiveness is an urban policy that manifests economic supremacy over other cities according to a ranking system.

\section{Economic Competitiveness in Cities and Metropolises}

Economic competitiveness describes a state where a country provides commodities and services internationally in a bid to increase the income of its citizens (Dadashpour 
\& Ahmadi, 2010). One of the goals of economic competitiveness is to boost welfare and develop a competitive framework in society (Ghorbani et al., 2014).

The process of economic globalization has brought about structural and functional changes to the process of urbanization, especially in cities and metropolises. As suggested by the theory of the World City, cities have grown particularly important with respect to their global function in the national economy (Pourahmad et al., 2011). In recent decades, cities, especially metropolises, have been the subject of innovation, information economics, management, and concentration of capital, among other things (Castells, 2001). It is in the form of a phenomenon called patriarchal economics in the world economy (Ali Akbari et al., 2019). One of the main economic functions of metropolises is connecting national and regional economies to the advanced global economy (Sassen, 2005). Metropolises provide a host of comparative advantages such as innovation, technology, specialization, internationalization, etc. However, for economic competitiveness, it is essential to foster factors that help achieve sustainable growth and development. According to Hausmann and Klinger (2007), a shift from comparative advantages to competitive advantages is deemed essential to ensure productivity and promotion (Hausmann \& Klinger, 2007). Therefore, according to urban economy approaches, the metropolitan system offers an opportunity for national and international competitiveness.

\section{Informal Economy}

The formal section represents activities that are transparent and recorded at national accounts. However, informal sector describes economic activities that are carried out through informal and illegal activities like informal services, the added value of which is not taken into account (Maddah \& Noe Iran, 2012). It is difficult to identify and measure the informal economy because informal jobs are diverse and constantly changing (Daniles, 2004). One of the major problems in underdeveloped and developing countries is the informal economy that influences economic activities in the formal sector. Most of these challenges are related to smuggling, tax evasion, informal accommodation, informal jobs, etc., which are inefficient and unproductive (Porta \& Shleifer, 2014). According to the United Nations' report (2020), informal employment is a serious challenge in countries with rural populations worldwide (UN, 2020). In their theory of informal economy, Litu quoted from Hernando Di Soto stressed the inability of developing countries to generate capital along with the government's inadequate support for informal employment (Litu, 2017). He argues that in these countries, people are drawn to informal economy due to the government's reluctance to support growth conditions (Morrison, 2018). This type of economy is characterized with reliance on local resources, low capital, limited activity, and lack of expertise and skills and activities that are beyond the formal system. The economy has grown alongside the formal economy in large cities over the past few decades. The reason is the income gap between urban and rural communities. The migration of rural population to cities and their settlement on the outskirts of large cities and metropolises through informal settlement have strengthened the urbanization system and highlighted the importance of this sector. Under such circumstances, as stated by Douglas North (2013), the informal sector can 
dominate the economy and constrain competitiveness (North et al., 2013). According to the study of Escobari et al. (2019), in order to address informal economy in cities, local institutions must be reinforced along with regional policy in order to cement economic diversity and job opportunities. There is a significant relationship between economic diversity and urban success, meaning that cities can help fortify urban economy through a raft of growth and development strategies (Escobari et al., 2019). So, the informal sector, as part of the economy of all developed and underdeveloped countries, complements the urban economy.

\section{Research Method}

This descriptive-analytical method is based on official employment data from eight metropolises of Iran in three economic sectors, i.e., industry, services, and agriculture. Data was collected from the analysis of documents, official statistics, and library resources. The collected data were analyzed using two models of TOPSIS and numerical taxonomy. TOPSIS is a multi-criteria decision-making technique for prioritizing alternatives. Numerical taxonomy is also a tool for ranking, classifying, and finally selecting the best options. In this paper, a meta-analytical approach to TOPSIS and TASONOMY models has been adopted. That is, it compares data and results reported by different researchers. The above two models enable the comparison, ranking and analysis of study data, and indices (i.e., population, urbanization and informal economy) under competitive conditions. Therefore, instead of attempting to provide new data and indicators, this paper seeks to shed light on the relationships governing the informal economy and the competitiveness of eight Iran's metropolises based on the available data. In this way, while discovering the determinants of the informal economy growth in Iran, particularly its metropolises, new results could be brought to light. The metropolises were selected based on their population (more than one million people) and instrumental regional role and geographical location. To determine the competitiveness of Iranian metropolises, the first 14 economic indices including employment rates of men and women, participation rates of men and women, the share of employment in industry, services, agriculture, and education sectors, the number of industrial workshops, per capita export, job opportunities, the number of operating companies, international activities, and GDP per capita are considered. Then, using the entropy method, they are weighed, and the results are presented in Table 1 and Fig. 9.

\section{Research Area}

Iran is a country in southwest Asia with a population of 84 million, as pointed in Worldometer elaboration of the latest United Nations data (see https://www.worldometers. info/world-population/iran-population/). 


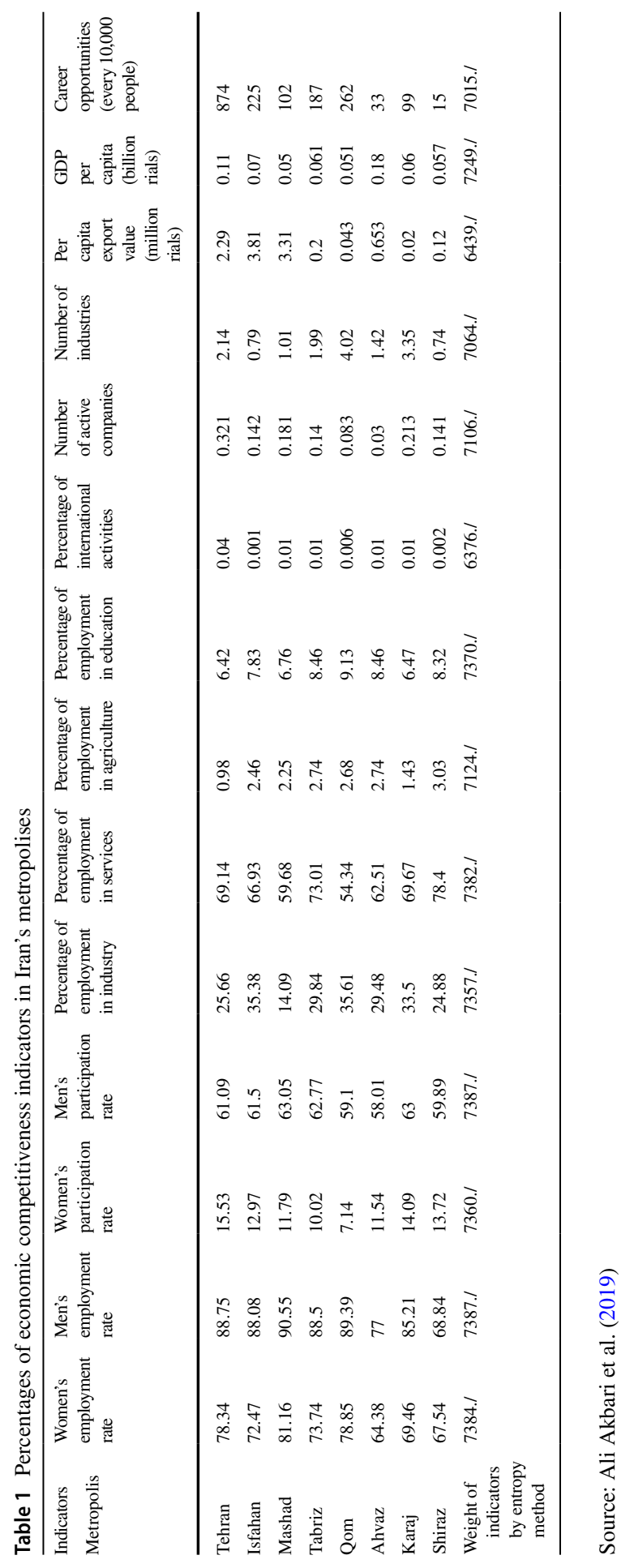


In recent decades, the growth and development of metropolises in Iran have been affected by several important indicators. These indicators could be classified into six groups:

Political: Iran's political developments such as the 1979 Revolution have been effective in structural and functional changes in cities. Given that the government in Iran is centralist, this approach has played a pivotal role in concentrating population and activity in large cities, as this process has led to challenges in large cities. From a political point of view, public participation in Iran's urban management history has not been a long-established tradition. In 1998, the first elections of the Islamic Council of Cities marked a step forward in policy-making and management of the urban system, and these councils were integral to the expansion of urban development in Iran.

Social and cultural: Urban development has a direct relationship with social and cultural development of Iran. With the social and cultural development of modernism and postmodernism, it found a place in urban planning and architecture of Iran. However, it was not in line with the values of the Iranian-Islamic community. Population density in metropolises, surge of urban specialists, change of life pattern from rural to urban after the 1970s, the growth of marginalization, consumerism, among other things have been manifestations of social and cultural indicators in urban growth and development of Iran.

Economic: Urban economy offers huge capacities for urban development. Iranian oil economy's support for the urban economy has bolstered growth and development of urbanization. Hence, factors such as foreign investment, increased GDP, increased per capita income of citizens, growth of inflation, urban poverty, and informal economy could be mentioned for this index.

Physical: One of the hallmarks of urban development in Iran is the physical growth of cities. The transformation of rural into cities, the construction of 28 new cities, unbalanced urban growth, high-rise and vertical urban planning, among other things illustrate the trend of changes in the physical index.

Technological: In recent decades, the development of information and communication technology has played a crucial role in urban development management. In Iran, the production, processing, and distribution of information have been a major problem in urban development planning and management. Over the last two decades, the national e-government policy and the approach to smart cities have highlighted the role of this indicator in the urbanization and urban development system.

Environmental: Balanced urban growth and development are key principles of sustainable urban development. Proper location, city form, urban development policies, etc. are determinants of urban sustainability or instability. In Iran, urban population growth and lack of effective applications in the urban system have given rise to 


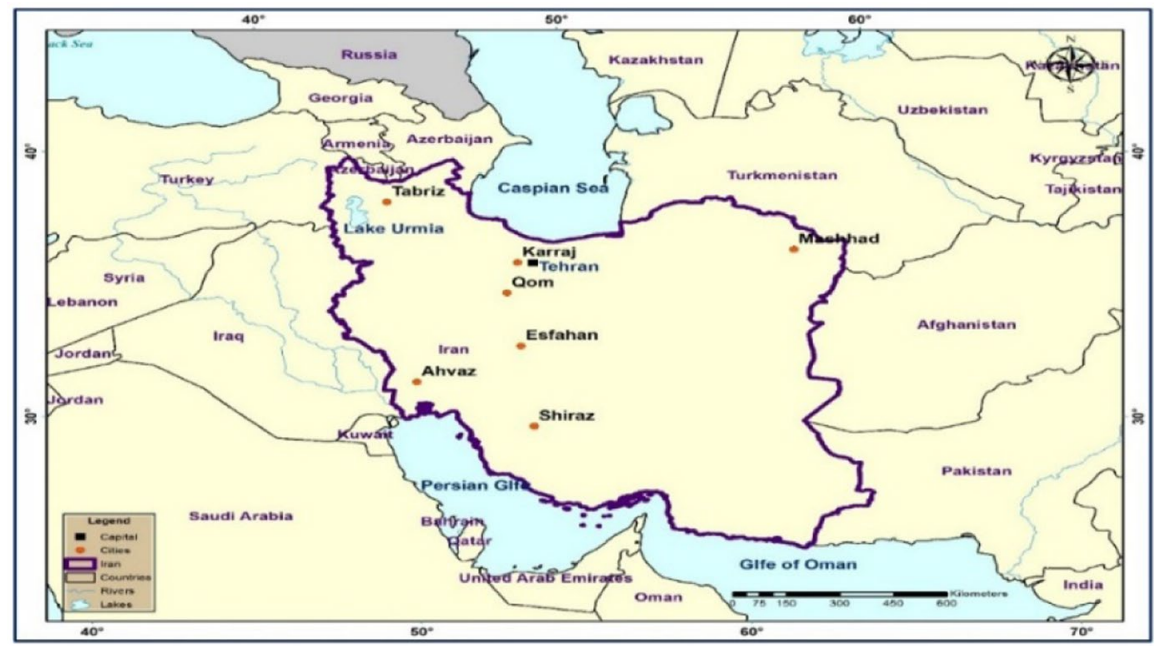

Fig. 5 Iran's geographical position and its metropolises

environmental challenges such as pollution (water, soil, and air), forest degradation in northern cities of Iran, and per capita reduction of urban green space. However, with the implementation of the EGO system, investment in the recycling of municipal waste, and increase of per capita, important steps have been taken to develop green space.

There are currently 1245 cities and 8 cities a population of more than 1 million people in Iran, which are referred to as metropolis. The research area covers eight metropolises including Tehran, Mashhad, Isfahan, Tabriz, Shiraz, Karaj, Ahvaz, and Qom. Figure 5 shows the geographical position of Iran and its metropolises (Fig. 5).

\section{Analysis of Indicators}

\section{Informal Economy in Iranian Cities}

In recent decades, Iran's economy, fueled by oil revenues and modernization, has shifted from agribusiness to the service sector and, recently, to IT and ICT through development plans. According to the latest official census, $49.1 \%$ of the active population and $57.75 \%$ of the working population in metropolises are employed in the service sector (Iran Statistics Center, 2019). The informal economy of Iran has four main characteristics:

First: Unproductive service activities outpace other activities.

Second: The factors contributing to the expansion of the informal sector (population growth, migration, and urbanization) are stronger in Iran than in other countries. 
Third: International sanctions have fueled rising inflation, shrinking economic competitiveness, and informal sector growth.

Fourth: With the growth of the informal sector, informal jobs eclipse formal employments (Sadr Mousavi et al., 2016). The amplified share of informal economy has been instrumental to exacerbating pollution and environmental degradation, threatening urban spaces such as suburbs, and escalating poor housing and informal settlements, to mention a few. According to the report issued by IMF, more than $31 \%$ of economic activities in Iran come with the purview of informal economy. According to this report, based on 1991 to 2015 statistics, informal activities make up more than $31.1 \%$ of Iran's GDP during these years. With informal sector accounting for $31 \%$ of total economic activity, Iran is ranked 30th in the world.

The government has been struggling with the implementation of socio-economic growth and development strategies, and thus, GDP data has changed over the years. Research shows that the share of the informal economy in GDP was 19.7 in the 1980s but spiked to 35.6 in the 2000s (Maddah \& Noe Iran, 2012). One of the determinants of structural-functional changes of Iran's cities in the decades following the 1979 Revolution was transformed economy of Iranian metropolises. Studies on the informal economy of Iran reveal that in post-2000 Revolution, the share of informal economy has soared, with this share being higher in large cities and the metropolises. Tehran, as the capital of Iran, along with other largest metropolises accounted for $68 \%$ of GDP the services sector (Tavakkolia \& Zarghami, 2016). This trend exhibits changes in the urban economy, which have induced variations in urban spaces (Mahmoudi, 2013). The socio-economic inequalities in Iranian cities and the disturbed balance of job opportunities in the urban economy have heightened the tendency for the informal sector (Veysiyan et al., 2016). This inequality has been primarily a ramification of rural-urban migrations in which people move to cities and metropolises for economic purposes. By establishing informal settlements, they have formed the marginal fabric of large cities and aggravated urban poverty (Sadr Mousavi et al., 2016). For example, in Ahwaz's metropolis, 30\% of immigrants have informal settlements and reside on the outskirts of Ahwaz. Thus, there is a significant positive relationship between rural-urban migration and marginalization (Ibrahim zadeh et al., 2010). The latest research on informal employment in one of Iranian cities shows that the concentration of informal employment in urban centers is closely tied to social instability. This means that in cities with intense informal employment, social instability has also been intensified (Nastaran et al., 2018). The expansion of urbanization in recent decades and the government's inability to create employment have played a major role in the growth of the informal sector in the economy of Iranian cities. Inflation, rural-urban migration, corruption, and economic rent and rising prices, and unemployment rate have exerted a prominent impact on the growth of informal economy in major cities and metropolises of Iran (Salimifar \& Keyvanfar, 2011). Therefore, it can be argued that increasing the share of informal sector in Iranian cities has deteriorated the performance of official economy of cities and suppressed their competitiveness. 


\section{Population Increase}

In the wake of modernism and the adoption of centralization approach in Iran since the 1960s and following the strategy of industrialization and establishment of industries on the margin of metropolises such as Tehran, Tabriz, Mashhad, and Isfahan, the rural-urban migration has actually increased population and reinforced activities in large cities of Iran. As a result, the urban population has been growing dramatically for about 40 years since 1979 Revolution and the urbanization of Iranians have become more apparent. As shown in Fig. 6, the urban population spiked from 54.3\% in 1986 to 74 in 2016, while the rural population fell from $45.7 \%$ in 1986 to $26 \%$ in 2016 (Fig. 6).

The highest population growth rate in Iran was reported in 1986 census according to which the annual population growth was estimated at 3.9, an unprecedented figure in Iranian history. The urban population growth has also picked up pace since the 1979 Revolution (Rezaie, 2010). The highest annual population growth was estimated in 1986 census and the lowest in 2016. Figure 6 shows the annual growth of population and urbanization in a 40-year period after the 1979 Revolution (Fig. 7).

\section{Urban Growth}

There is a positive relationship between urban development and national development. After the 1979 Islamic Revolution, governments were chiefly city-centered. The emergence and growth of metropolises and the changing pattern of from rural to urban life along with $20 \%$ growth of urbanization during four decades reflect the governments' approach to urbanization and urbanization in Iran. During this period, the execution of growth and development strategies with a centralized approach in Iranian cities have made structural-functional changes in the urban network. This

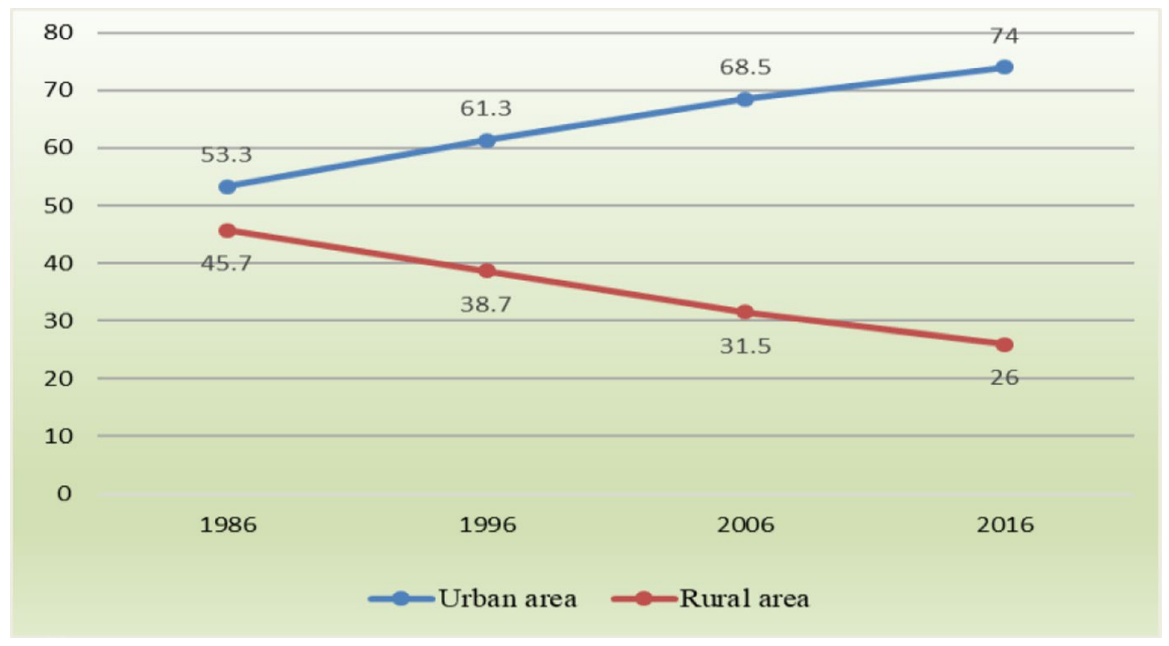

Fig. 6 The percentage of urban and rural population changes 


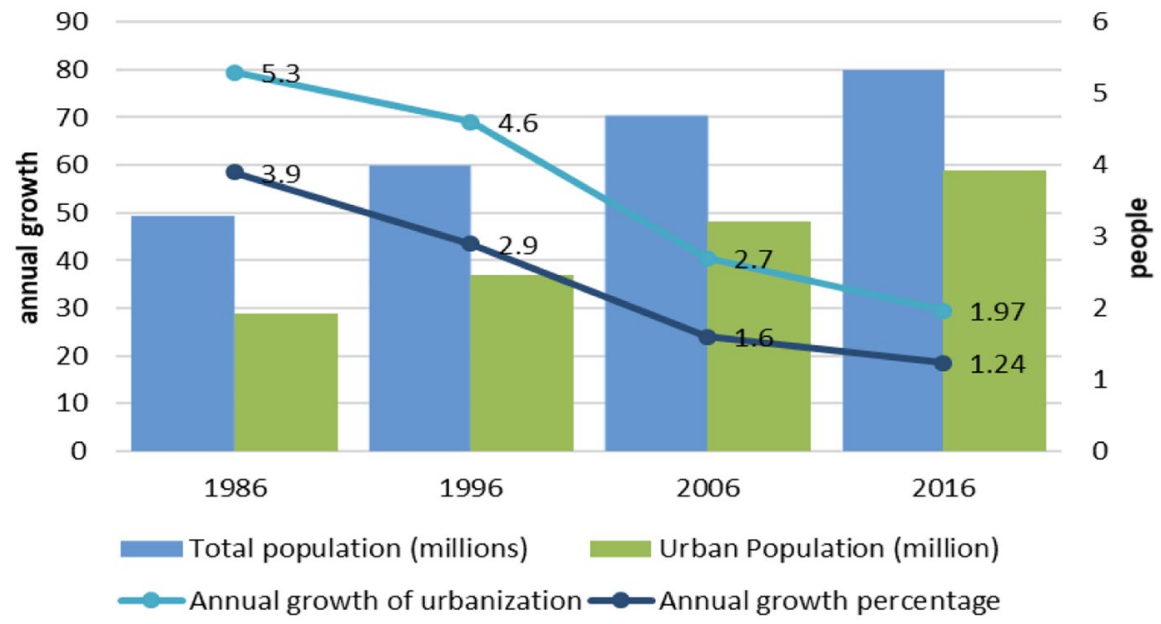

Fig. 7 Population and urbanization growth in Iran

trend has provoked inequality in the urban system, economic dependence, economic dichotomy, polarization of capital, class division, and population mobility, especially the rural-urban migration (Pilehvar \& Pour Ahmad, 2004). The study on urbanization growth exhibits the changing pattern of Iranian life from rural to urban style after the 1979 Revolution. For the first time, the urban population reached $54.3 \%$ in 1986 census. The change of urban living patterns to rural areas has been accompanied by the elevated share of services and informal economy, especially in large cities. It is because the informal sector is a major source of employment in large cities and the metropolises of migrant cities. Therefore, the direct relationship between urbanization growth and urbanism in Iran as well as the changing pattern of urban economy to service and nonproductive sectors is conceivable. It also seems that the growth of population and urbanization in Iran has been one of the main drivers of informal sector expansion in large cities of Iran.

\section{Informal Economy in Metropolises}

In recent decades, oil production and integration into the global economy have pushed the growth of Iran's economy towards modernization and exogenous development. According to Hausmann and Rodrik (2003), an endogenous model is required for sustainable economic growth and development (Hausmann \& Rodrik, 2003). In the Fourth Global Report on Urban Competitiveness, Tehran and Ahwaz ranked 167th and 198th among 200 metropolises in terms of sustainable competitiveness. Nevertheless, none of Iranian metropolises were among the top 200 cities in the world with respect to economic competitiveness in 2019-2020 (Kamiya \& Ni, 2020). The rapid growth of urbanization in less developed and developing countries has spurred the concentration of population and activities in large cities, which has been characterized with inefficiency, rising unemployment, and informal employment in these countries (Zafari et al., 2018). The formulation and implementation 
of modernization and development programs in Iran since the 1960s have resulted in the concentration of industries and job opportunities in cities, particularly the metropolises. The trend of rural-urban migration following Land Reforms in 1961 channeled population to large cities, giving rise to a host of problems such as housing, unemployment, poverty, and informal sector growth (Zafari et al., 2018). Setting up industries on the outskirts of metropolises also attracted the working population and rural workers to these areas (Pour mohammadi, 2018). Thus, the migration of rural residents to metropolises led to the explosion of population and activity. The natural growth of urban populations and the conversion of villages into urban centers also intensified this process, with $26.9 \%$ of the total population and $36.6 \%$ of urban population of Iran residing in eight metropolises. Figure 8 shows variations in Iranian population living in metropolises (Fig. 8).

In this process, the population was partially shifted towards the informal sector to tackle the challenges associated with living in metropolises (Jamali et al., 2008). According to the ILO report, informal employment has been on rise in Iran (ILO, 2012). These developments transformed the socio-economic foundations of cities and increased population, especially in Iranian metropolises. The diversity and breadth of the informal sector and its contribution to the Iranian urban economy, coupled with the need for government investment in urban infrastructure, have doubled the capacity of urban development. One major reason for the growth of informal economy in Iranian metropolises has been the flow of immigration over the past few decades. According to the latest official statistics of Iran, $82.9 \%$ of immigrants flowing to cities, especially metropolises, are 20 to 29 years old (Iran Statistics Center, 2019). Thus rural-urban immigrants are mainly young, low-skilled workers who are effortlessly drawn to the informal sector and forced to deal with the low wages and unsavory living conditions in metropolises. For example, in Tabriz's metropolis, $37.2 \%$ of workers are informal immigrants, $80 \%$ of whom are intra-provincial immigrants. As for the level of

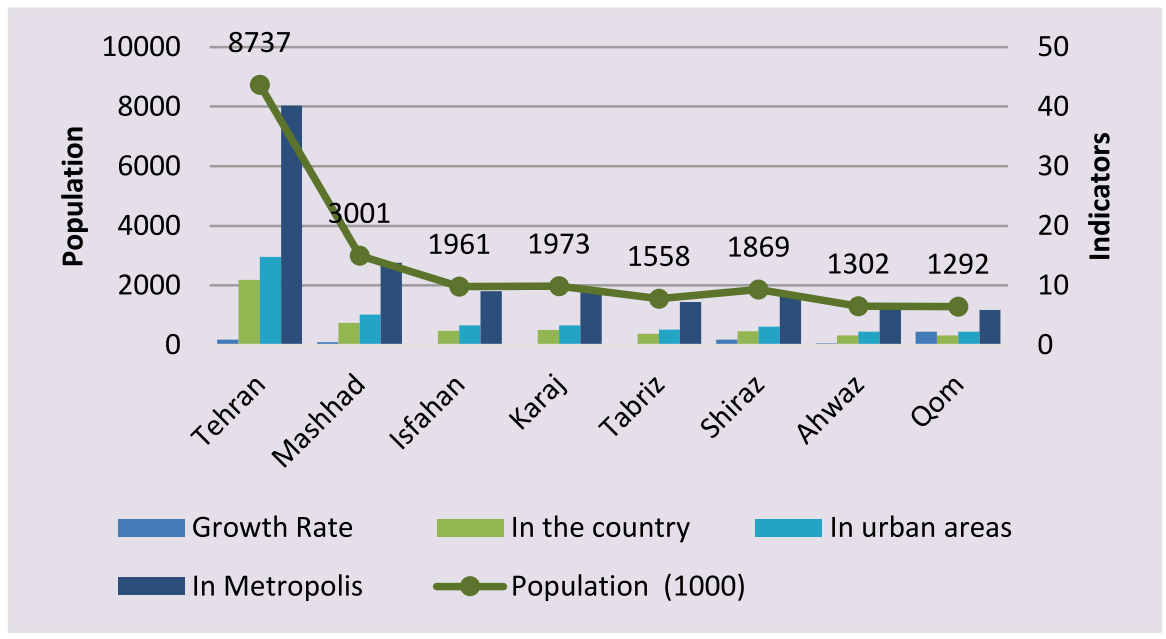

Fig. 8 The percentage of growth rate and population change in Iran's metropolises (in 2016) 
education, $19.7 \%$ of these immigrants were illiterate. New surveys in Tehran (the capital) show that $22.7 \%$ of Tehran's migrants are employed in the informal sector and settle on the outskirts of Tehran, which are considered as deprived areas rife with informal housing in the urban economy (Mirzaei et al., 2015). In the past few decades, the informal sector has been growing in Iranian urban economy. This is chiefly because the post-1979 Revolution has drawn much of the urban workforce (MSRT, 2001). The absorption of urban labor force has also improved the flexibility of national economy activities (Amozegar, 2008). It has also contributed to the reduction of unemployment in urban areas (Rabbani et al., 2009) and built the capacity for urban employment. Regarding job opportunities, Tehran (capital) with 874, Isfahan with 225, and Qom with 262 are significantly different due to industrialization. The informal sector has considerably improved the urban business environment, the employment of poor and marginalized urban residents, and the alleviation of urban poverty (Haji Lu et al., 2016). Therefore, there seems to be a meaningful relationship between urbanization, metropolises growth, and informal economy in Iran.

\section{Economic Competitiveness in Metropolises}

Urban competitiveness is one of the goals of governments and planners in the national and regional development process. Considering the indicators of urban competitiveness offers deeper insights into urban economic policies and strategies (Singhal et al., 2013). The rapid growth of urbanization in Iran suggests that due to the concentration of activity and population in large cities and metropolises, about $31.6 \%$ of Iranian population and $44 \%$ of urban population inhabit in 15 major cities and metropolitan areas (Ali Akbari et al., 2019). Table 1 shows the employment status in terms of economic competitiveness indicators in eight Iran's metropolises. Table 1 also illustrates the imbalanced employment situation in these metropolises. The highest rate of female and male employees was observed in Mashhad (81.16 and 90.55) and the lowest in Ahvaz (64.38 and 77.00), respectively.

The majority of industrial workers dwelled in Qom (35.61), and the lowest number of industrial workers were residents of Mashhad (14.09). Also, the highest number of service workers was recorded in Shiraz (78.40) and the lowest in Qom (54.34). Most of the agricultural workers lived in Ahwaz (2.74), while Tehran had the lowest number of agricultural workers (0.98) (Table 1).

One of major issues in urban competitiveness is the share of informal sector (informal activities, informal housing, etc.) in the economy of metropolises. This sector curbs competitiveness as an urban issue. Due to the polarization of society, widening socio-economic gap, pollution, and environmental degradation in major cities and their surrounding areas (Ali Akbari et al., 2019), it presents an important obstacle to sustainable urban competition in various economic, social, and environmental dimensions (Ghorbani et al., 2014). The analysis of economic indicators in eight Iran's metropolises shows that Tehran (0.201) and Isfahan (0.174) are particularly distinct from other metropolises, followed by Mashhad (0.148), Karaj (0.121), Shiraz (0.107), Tabriz (0.101), Ahvaz (0.81), and Qom (0.67), respectively (Mansaf et al., 2014). The latest survey on economic competitiveness in eight Iran's metropolises using TOPSIS and 
Table 2 The rank of Iran's metropolises according to taxonomy and TOPSIS index

\begin{tabular}{lllllllll}
\hline Metropolises & Tehran & Isfahan & Mashad & Tabriz & Qom & Ahvaz & Karaj & Shiraz \\
\hline $\begin{array}{l}\text { TOPSIS } \\
\text { index }\end{array}$ & 0.504 & 0.464 & 0.434 & 0.416 & 0.389 & 0.358 & 0.333 & 0.325 \\
$\begin{array}{l}\text { Degree } \\
\begin{array}{l}\text { Taxonomy } \\
\text { index }\end{array}\end{array}$ & 0.669 & 0.671 & 0.701 & 0.603 & 0.709 & 0.71 & 0.696 & 0.711 \\
\begin{tabular}{l} 
Degree \\
\hline
\end{tabular} & 1 & 2 & 5 & 3 & 6 & 7 & 4 & 8 \\
\hline
\end{tabular}

Source: Ali Akbari et al. (2019)

numerical taxonomy suggests that Tehran ranks first as the most competitive city, while Shiraz is ranked last. Table 2 and Fig. 8 show the ranks of metropolises (Table 2 and Fig. 9).

According to Fig. 8, Tehran has the highest, and Shiraz has the lowest competitiveness indices among Iran's metropolises. This trend has fortified competitiveness in Tehran metropolis compared to other Iran's metropolises (Feizpour et al., 2015). Tehran accounts for more than a quarter of Iran's GDP, which indicates its conspicuous role in Iran's national economy (Tavakkolia \& Zarghami, 2016). At the national level, due to political centrality, a greater share in GDP, the establishment of international companies, and the greater relevance to urban and regional networks, Tehran is the best metropolises of Iran. However, this position of Tehran (I) seems vulnerable. One-dimensional economic policies, management challenges, marginalization growth, class divisions, etc. are among the factors that diminish Tehran's international competitiveness.

\section{Discussions and Analyses}

In the 1960s, the approach to modernism with the strategy of harmonized industrialization and land reform helped increase the flow of rural-urban migration. Since the 1970s, the Iranian government has strengthened the urban economic cycle

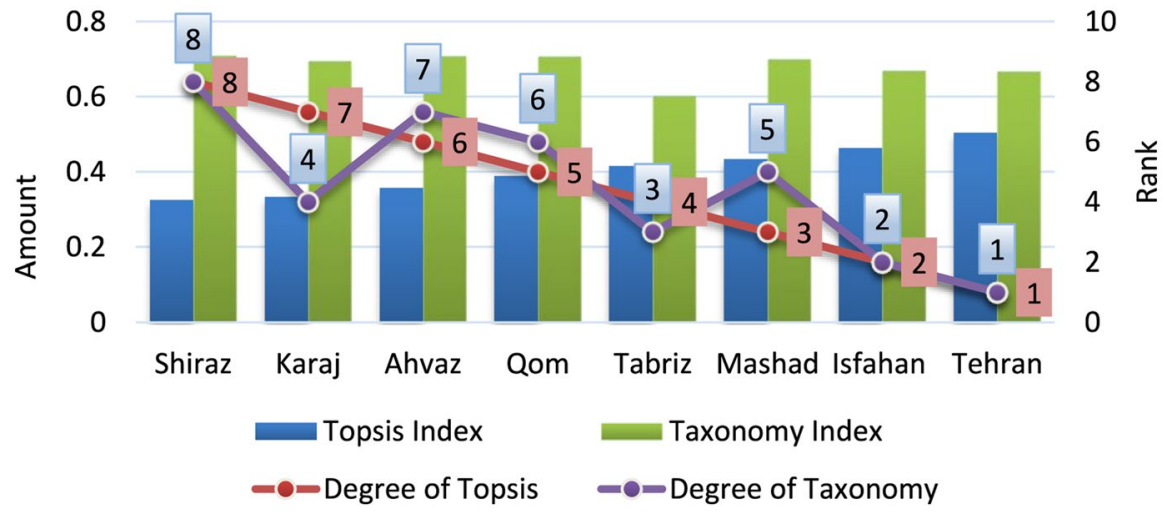

Fig. 9 The amount and rank of Iran's metropolises compatible by taxonomy and TOPSIS index 
by exploiting oil revenues and dominating capital flows and wealth (Rahnamaei, 2009). The government, with its urbanism approach, changed the interaction between rural and urban areas. Following that, the dependence of the rural system on the urban system was intensified (Meshkini \& Rahimi, 2014). Also, in this decade, the Arab-Israeli war and the Arab sanctions on Western countries provided an apt opportunity to increase Iran's oil exports. Therefore, the substitution of oil exports increased oil revenues and foreign investment in Iran. In this process, the urban planning system and the construction industry flourished in cities and metropolises. However, in the 1980s, the Iran-Iraq war (for 8 years) slowed down the growth of war-torn cities. Since the 1990s, the growth of the urban population and the construction of 28 new cities targeted urbanization and urban planning with the support of the government and the oil economy and revealed dependent and problematic urbanization, especially in the metropolises of Iran. The study of national development and urbanization system trend in Iran shows the lack of a national and indigenous growth and development model adaptable to IranianIslamic values and has mounted important challenges to social, cultural, political, physical, and environmental indicators in the process of national growth and development (Salimi \& Maknoon, 2018). Therefore, the introverted approach and decentralization of metropolises can be an effective strategy for the sustainability of national development and the urban economy system in Iran.

\section{Conclusion}

Multiple years of recession have severely undermined the welfare of the Iranians and put unprecedented strain on the most vulnerable which raises the urgency of reforms. Mitigation measures have partly offset these pressures in the past but remain insufficient due to lack of accurate targeting mechanisms and fiscal constraints.

After the 1960s, the anomalies of urban development came to surface with oil-based industrialization, the weakening of the rural economy, rapid population growth, and government investment in large cities. As such, social (marginalization, class gap, etc.), economic (inflation, unemployment, urban poverty, etc.) cultural (anonymity, despair, etc.), physical (informal housing, housing shortages, etc.), environmental (types of pollution, etc.), and managerial (reduction of citizen participation, etc.) challenges in the urban system of Iran emerged. Iran's approach to modernism and structural-functional changes, which stems from population growth and urbanization, has spurred the growth of the informal economy. Development planning in the form of 5-year development plans (6 plans) before the 1979 Revolution and 5-year development plans in the Islamic Republic of Iran after the 1979 Revolution have provided the basis for reinforcement of the urban system in Iran and the recession of the rural system. The outcome of this accelerated trend of urbanization and urbanization was the establishment of one metropolis in the 1980s and 8 metropolises in the 2010s. The expansion of formal and informal economy in metropolises is positively linked 
to rural-urban migration and the service economy. On average, $57.75 \%$ of the economic activities in metropolises are related to service sector. The economic dependence of Iran's metropolises on oil revenues has provoked urban and rural dichotomy, socioeconomic division, urban poverty, informal housing, etc. in the last two decades, which has also decreased competitiveness. This trend has made the informal sector's contribution to the urban economy more pronounced. In some Iran's metropolises, such as Tehran, Mashhad, and Tabriz, the informal sector accounts for up to $35 \%$ of national GDP. Thus, with the complexity of urban issues and the growth of informal economy, attention should be given to the sustainability of cities and competitiveness of Iran's metropolises to elevate the position of Iranian metropolises in the process of urban competitiveness among the developing countries. Therefore, strategies such as decentralization of population and activity in Iran's metropolises and strengthening of formal economy along with increased competitiveness should be prioritized. The process of contracting the share of the informal sector in urban economy should also be assessed and managed. The use of smart, innovative, and technology-based approaches to the service economy can be an effective step in the formation of productive, dynamic, and competitive metropolises. This trend can shore up balanced development at the national-regional level of Iran and tackle the issues of class division, marginalization, and urban poverty, thereby improving the position of Iran's metropolises in national and international competitions. To improve the competitiveness of Iran's metropolises, it is crucial to promote activities that are tailored to the capacity and potentials of the local labor force and to strengthen the productivity of cities. As Rodrik (2013) notes, policies such as investment in education, skills training, administrative capacity building, and governance should be top on agenda (Rodrik, 2013) for promoting competitiveness. This approach to socioeconomic dynamism, new businesses, sustainable employment, and sustainable growth will drum up competition at national and international arenas. Therefore, structural-functional developments have wielded influence on improving competitiveness in Iranian cities, especially its metropolises, which can reduce the share of informal employment. Also, an effective strategy for competitive economic growth in Iran is institutionalization and improvement of governance as well cultivation of an open economy unrestricted by sanctions. In such a situation, both economic competitiveness and informal economy's growth are hindered.

\section{References}

Ali Akbari, E., Khodadad kashi, F., \& Komasi, H. (2019). Evaluating the economic competitiveness of metropolises in Iran. Journal of Regional Planning, 8(29), 13-26.

Amozegar, J. (2008). Gray economics, Tebian cultural and information institute. Qom.

Castells, M. (2001). Economics, culture in the information age; translated by Ahmad Aghykian and Ahmad Khakbaz. New Design Publishing.

Dadashpour, H., \& Ahmadi, F. (2010). Regional competitiveness as a new approach to regional development. Yas Strategy Journal, 22, 51-80.

Daniles, P. W. (2004). Urban challenges: The formal and informal economics in mage-cities. Cities Journal, 21(6), 501-511. 
Delbari, M. (2014). Economic competitiveness of cities with an emphasis on factors affecting urban competitiveness index (GUCI), the first national conference in search of cities of tomorrow, Tehran, October 2014.

Eide, E. B. (2014). A report of the Global Agenda Council on Competitiveness, The Competitiveness of Cities. In Swiss: World Economic Forum.

Escobari, M., Seyal, I., Morales-Arilla, J., \& Shearer, C. (2019). Growing cities that work for all: a capability-based approach to regional economic competitiveness. https://www.brookings.edu/ wp-content/uploads/2019/05/GrowingCitiesthatWorkforAll-FINALforWeb.pdf

Feizpour, M. A., Mojibifar, M., \& Mehdizadeh, M. (2015). Urban competitiveness and Tehran position among the metropolises of Iran, the conference on the centralization and capitalization of the capital, Iran, Tarbiat modares university.

Ghorbani, R., Jafari, F., Maboodi, M.T., Hosseinabadi, S., Gharavi, M., Eghdam,H., \& Zafari, D. (2014). An attitude to modern Urban Planning Patterns. Tabriz, Foroozesh.

GUCP. (2010). Global Urban Competitive Index Rankings 2009-2010, Center for City and Competitiveness, Chinese Academy of Social Sciences, Retrieved from http://www.gucp.org/en/

Haji Lu, M., Parsipour, N., Hosseinzadeh Saadat, M., \& Bagheri, H. (2016). Review of policies for organizing informal economy in developing countries, First International Conference on Urban Economics, Tehran.

Hausmann, R., \& Rodrik, D. (2003). Economic development as self-discovery. Journal of Development Economics, 72(2), 603-633.

Hausmann, R. Rodrik, D. (2002) Economic development as self- discovery, NBER Working Paper No. $8952.1-43$.

Hausmann, R., \& Klinger, K. (2007). The structure of the product space and the evolution of comparative advantage. CID Working Paper Series 2007.146, Harvard University, Cambridge, MA, April 2007. http://nrs.harvard.edu/urn-3:HUL.InstRepos:42482358

Ibrahim zadeh, I., Varesi, H., \& Ibrahimi, M. (2010). The role of rural migration in nonformal habitat (case study: Ahvaz Metropolis). Journal of Rural Research, 1(1), 167-191.

ILO. (2012). Measuring the economically active in population censuses: A handbook. New York.

Jamali, F., Sadr Mousavi, M., \& Parvin dokht, L. (2008). Investigating the characteristics of informal jobs in Tabriz mother city. Geographical Research Quarterly, 89, 19-46.

Kamiya, M., \& Ni, P. (2020). The Global Urban Competitiveness (GUCR) (2019-2020) The World:300 years of transformation into city, Chinese Academy of Social Sciences (CASS) and UN-Habitat. https://unhabitat.org/sites/default/files/2020/10/global_urban_competitiveness_report_20192020_the_world_300_years_of_transformation_into_city.pdf

Kargar Samani, A., Kord, A., \& Khodad Hosseini, S. H. (2014). The impact of urban competitiveness on national competitiveness. Quarterly Outlook for Business Management, 13(4), 123-139.

Khajehpour, B. (2020) Anatomy of the Iranian Economy, published by the Swedish Institute of International Affairs I UI.SE. Drottning Kristinas väg 37, Stockholm.

Litu, A. (2017). Lessons from Hernando De Soto on the informal economy, Informal Business Analysis.https:// litualex.wordpress.com/2017/08/03/lessons-from-hernando-de-soto-on-the-informal-economy/

Maddah, M., \& Noe Iran, F. (2012). Estimating the value of informal economy in Iran based on environmental variables: The Kalman filter approach. Journal of Economic Modeling Research, 3(10), $1-19$.

Mahmoudi, Y. (2013). Informal economy and its impacts on the city: Case study; Baneh City, first national conference on integrated urban management and its role in sustainable development, Sanandaj: Islamic Azad University, Sanandaj Branch.

Mcmillan, M., Rodrik, D., \& Verduzco-Gallo, I. (2014). Globalization, structural change, and productivity growth, with an update on Africa. World Development, 63, 11-32. https://doi.org/10.1016/j. worlddev.2013.10.012

Meshkini, A., \& Rahimi, H. (2014). Analysis of space and state concepts in state andurbanization theory of Iran. MJSP, 17(4), 87-110.

Mondal, P. (2021). Competition: Definition, characteristics, types and importance, In https://www. yourarticlelibrary.com/sociology/competition-definition-characteristics-types-and-importance/ 35120. January 22.2021.

Morrison, R. (2018). Hernando de Soto: How to make the Third World richer than the first? Foundation for Economics Education, Monday, August 20. https://fee.org/articles/hernando-de-sotohow-to-make-the-third-world-richer-than-the-first/ 
MSRT (Ministry of Science, Research and Technology). (2001). Graduate report of the whole country, Tehran.

Mirzaei, J., Ahmadi, S., \& Lorestani., A. (2015). Spatial analysis of prosperity levels in Tehran metropolis from the perspective of urban economics. Journal of Urban Economics and Management IUESA, 3(11), 59-77.

Monsef, A., Sameti, M., \& Mousavi Madani, M. (2014). Ranking eight metropolitan cities of Iran in terms level of development AHP and 2011 classification. Development Economy and Planning Journal, 3(1), 51-73.

Muller, L., \& Webster, D. (2000). Urban competitiveness assessment in developing country urban regions: The road forward, the World Bank, Washington D. C.

Nastaran, M., Rabiei, K., \& Abdekhoda, K. (2018). The study of informal employment impacts on social sustainability; the case study of Baneh. Social Development \& Welfare Planning Journal, 10(37), $91-120$.

Nazmfar, H., Eshghi Chaharborj, A., \& Alavi, S. (2017). An investigation of the economic competitiveness status of cities of Iran. Journal of Urban Economics and Management, 5(20), 23-38.

Nejati Hosseini, S. M. (2011). Urban politics and urban diplomacy (from theory to experience). Journal of Historical Sociology, 3(2), 117-142.

North, D. C., Wallis, J., Joseph, W., Steven, B., \& Weingast, B. R. (2013). Limited access orders in the developing world : A new approach to the problems of development. World Bank Group. https://doi. org/10.1596/1813-9450-4359

Paliulis, N., \& Cincikaite, R. (2013). Assessing competitiveness of Lithuanian cities. Economics and Management., 18(3), 490-500.

Peter, K. K. (2013). The competitiveness of cities. UN Habitat Publication.

Pilehvar, A. A. (2020). Urban unsustainability engineering in metropolises of Iran, Iranian Journal of Science and Technology, Transaction of. Civil Engineering, 44(3), 775-785.

Pilahvar, A. A., \& Pour Ahmad, A. (2004). The process of metropolitan growth and development: A case study of Mashhad. Journal of Geographical Research, 36(48), 103-121.

Popescu, R. I. (2011). Study regarding the ways of measuring cities competitiveness. Economia. Seria Management, 14(2),288-303.

Porta, R., \& Shleifer, A. (2014). Informality and Development. Journal of Economic Perspectives, 28(3), $109-126$.

Pour Ahmad, A., Gharkhloo, M., \& Mousavi., S. (2011). Investigating the concepts and indicators of world theory. Bagh Nazar Journal, 8(16), 29-42.

Pour mohammadi, M. R. (2018). Housing Planning, Khome Publications, 14th Edition, Tehran.

Rabbani, R., Varesi, H., \& Taheri, Z. (2009). Analysis of the basic causes of formation of marginal settlementregionsinIsfahan(thecasestudy:ArzenanandDarak).GeographyandDevelopmentJournal, 7(13), 93-124.

Rabie, M., \& Khajooei, M. (2013). Explaining the competitiveness strategy of Tehran. Management Strategic Studies, 4(15), 37-56.

Rahnamaie, M. T. (2009). The government and urbanization theory. Journal of Urban Ecology Researches, 1, 143-165.

Rezaei, M. (2010). The influence of border markets on physical and economic growth of neighboring towns case study of border market of Bashmagh in Marivan City, MA thesis, Zanjan University, Zanjan.

Rodrik, D. (2013). The past, present, and future of economic growth, Global Citizen Foundation, WORKING PAPER 1, JUNE 2013. https://www.gcf.ch/wp-content/uploads/2013/06/GCF_Rodrik-workingpaper-1_-6.17.131.pdf

Rodrik, D., Mcmillan, M., \& Sepúlveda, C. (2016). Structural change, fundamentals, and growth: A framework and case studies. International Food Policy Research Institute.

Sadr mosavi, M., Poormohmmadi, M., \& Zafari, D. (2016). Studying and analyzing the role of rural migrations in creating the informal section (case study: Tabriz megalopolis). Journal of Urban Research and Planning, 7(25), 23-42.

Saez, L., \& Perianez, I. (2015). Benchmarking urban competitiveness in Europe to attract investment. Cities, 48, 76-85.

Salimi, J., \& Maknoon, R. (2018). Qualitative meta-analysis of scientific researches concerning the issue of governance in Iran. Journal of Public Administration, 10(1), 1-30.

Salimi, F. M., \& Keyvanfar, M. (2011). Unofficial economy in Iran and the inflation effect on it. Journal of Knowledge and Development, 17(33), 1-27. 
Sally, R. (2014). The competitiveness of cities, a report of the Global Agenda Council on Competitiveness, World Economic Forum, REF 040814.August 2014. http://www3.weforum.org/docs/GAC/ 2014/WEF_GAC_CompetitivenessOfCities_Report_2014.pdf

Sassen, S. (2005). The global city: Introducing a concept, Journal of World Affairs, winter/spring, xi (2).27-43.

Singhal, Sh., McGreal, S., \& Berry, J. (2013). An evaluative model for city competitiveness: Application to UK cities. Land Use Policy, 30(1), 214-222.

Snowdon, B., \& Stonehouse, G. (2006). Competitiveness in a globalized world: Michael Porter on the microeconomic foundations of the competitiveness of nations, regions, and firms. Journal of International Business Studies, 37(2), 163-175.

Statistical Center of Iran. (2019). General population and housing census throughout the Tehran, Tehran.

Tavakoli Nia, J., \& Zarghami, S. (2016). Economic globalization and its impacts on economic and spatial structure of metropolitans: The comparative study of the Tehran and Istanbul. Economy of Spatial Planning Journal, 20(3), 211-239.

The World Bank. (2020). Iran economic monitor weathering the triple-shock, publication design and layout by The Word Express, Inc. Washington, DC 20433, USA.

UN. (2006). Innovative policies for the urban informal economy-HABITAT: Nairobi.

UN. (2020). World Economic Situation and Prospects 2020. United Nations publication Sales No. E.20.II.C.1 New York. https://www.un.org/development/desa/dpad/wp-content/uploads/sites/45/ WESP2020_FullReport.pdf

Villamejor-Mendoza, M. (2020). Competitive cities: Implications for better public service. Policy Design and Practice, 3(4), 445-461.

Voinescu, R., \& Moisoiu, C. (2015). Competitiveness, theoretical and policy approaches. Towards a More Competitive EU, the Institute for World Economy, Procedia Economics and Finance, 22(2015), 512-521.

Vares, S. H., Mohammadi, S., \& Parvandi, Y. (2012). The Impact of Global Competitiveness on Economic Achievement: Providing a Model for Promoting National Competitiveness of Iran. Journal of Management Science of Iran, 2(7), 25-48.

Veysiyan, M., Mousavi, M., \& Rabbani, T. (2016). An analysis of the status of informal workers (case study of Qorveh City). Journal of Geography and Urban Space Development, 2(1), 111-123.

Yang, J. (2013). Credit risk spillovers among financial institutions around the global credit crisis: Firmlevel evidence. Management Science, 59(10), 23-29.

Yasouri, M., Hataminejad, H., \& Asad Zadeh, H. (2015). Centralization in Tehran, trends and policies. Simaie Danesh press.

Zafari, D., Sadr Mousavi, M., \& Pour mohamadi, M. (2018). Status of the informal sector in sustainability of urban economy (case study: Tabriz City). Human Geography Research, 50(3), 645-659.

Ziari, K., Hajian Hossein Abadi, M., \& Khavarian Garmsir, A. R. (2020). Making Competitive Cities in the Light of the Meta-SWOT Tool: A Case Study of Tehran, Iran. Planning Practice \& Research, 35(4), 466-484. https://doi.org/10.1080/02697459.2020.1757844

Publisher's Note Springer Nature remains neutral with regard to jurisdictional claims in published maps and institutional affiliations. 